\title{
Sovereign Democratic Transformation in Ecuador (2007-2016)
}

\author{
Ricardo Restrepo Echavarría ${ }^{1}$ \\ ${ }^{1}$ Universidad Nacional de Educación, Azogues, Ecuador \\ Correspondence: Ricardo Restrepo Echavarría, Universidad Nacional de Educación, Azogues, Ecuador. E-mail: \\ ricardo.restrepo28@yahoo.co.nz
}

Received: August 9, 2017

Accepted: August 18, 2017

Online Published: October 10, 2017

doi:10.5539/res.v9n4p20

URL: http://doi.org/10.5539/res.v9n4p20

\begin{abstract}
Between 1981 and 2007, Ecuador experienced neoliberal reforms coupled with an elite form of democracy. These led to slow growth, upwards redistribution, and political and economic instability. Since then, Ecuador adopted a Citizens' Revolution to counteract these economic and political forms of domination. This paper advances a few elements of the theoretical understanding of democratic justice inspired by the constitutional vision of Buen Vivir, and their policy applications in reconfiguring the political institutions that shape the state and its international relations. The application in the Citizens' Revolution movement and historical phase has helped advance the democratization of the Constitution, the Executive, the Legislative, the Judicial system, political rights, the right to life, freedom of expression, national natural resources and investments, external public debt, as well as social rights and the welfare state.
\end{abstract}

Keywords: democracy, democratic theory, Ecuador, Citizens' Revolution, politics, neoliberalism, justice

\section{Introduction}

In a world dominated by imperialism, poverty, political, environmental and economic crises, with feedback reward mechanisms for the protagonists of the sectors that drive such problems, one of the most important and urgent tasks for the social scientist today is to find promising ways in which humanity can alternatively re-organize itself, based not only in theoretical possibilities, but some real-life cases. One country that has made significant strides in confronting the national expressions of such world-problems, and whose experience can feed into thinking about facing them, is Ecuador. The task of the present paper is to suggest some theoretical frames and perform empirical analyses of Ecuador's transformations, which can serve the thinking for effectively facing such problems generally.

The rapid transformation of the Ecuadorian order baffles the intellect and perplexes the researcher. Always on the verge of a coup, Ecuador's mean head of state duration is but two years since Independence in 1830, whether under dictatorship or democracy. Instability, inequality, poverty and a highly primary export dependent economy seem to be some of the few constants. Until recently Ecuador was considered at risk of being a failed state by some, not without some ground. After a decade of increased instability, came another decade, however, in which Ecuador has seen a newfound stability. It remains to be seen whether its present democratic form can be sustained, but the change is evident. Since Ecuador's "return to democracy" in 1979, it has exercised three principal democratic models of theoretical interest: minimalist neoliberal democracy, neoliberal false democracy and a transition toward democratic justice, each marked by one of three distinct constitutions (1978, 1998 and 2008), popular participation and consent, rights, "basic interests" and aspiration satisfaction, as well as distinct stability levels and leadership types.

Restrepo (2017) analysed the neoliberal minimalist (1981-1997) and false neoliberal (1998-2006) forms of Ecuadorian democracy. In this paper, I wish to take the next step and look at the macroscopic changes of theoretical interest to democratic justice and Buen Vivir (Good Living or Sumak Kawsay, as it is called in the Constitution) since then (2007-2016), in the hope of providing a historically grounded theoretical analysis of Ecuador's recent evolution, which allows not only for a more profound understanding of Ecuador's reality but also some of the theoretical alternatives available to societies generally, in terms of their organization and orientation, and strategies to constructively change. There are four principal axes of domination Ecuador has needed to address to advance toward democratic justice and Buen Vivir: political, foreign, capital and ecological. In this paper we will address changes with respect to political and foreign domination. 


\section{Democratic Justice and Buen Vivir}

Ian Shapiro $(2005 ; 2006 ; 2011 ; 2012)$ has developed a theory of democratic justice that brings back justice into the political game and the present formulation takes central elements and inspiration from his account. Originating in proposals by sectors of indigenous peoples, Buen Vivir was established in the Ecuadorian Constitution as the ideal of just society in harmony with nature, to which society, the economy and public policy should aim. Very much in coincidence with democratic justice, Buen Vivir adds an agenda of decolonization and the recognition of the Earth's ecosystems as bearers of rights to be protected in these times of global ecological crisis.

In Shapiro's theory, unlike minimalist and false democratic theory, democracy's method is for abolishing domination, thus furthering justice. Domination is a form of illicit unfreedom embedded in correctable social organizations which undermine basic interests (sufficient food, housing, education, health, etc.). Power is not necessarily a form of domination, as power can also be an instrument of collective action for getting rid of domination, as in Haiti's blacks revolting against French imperial slavery, Simon Bolivar's army getting rid of Spanish colonial rule, while denouncing and constitutionally abolishing slavery in the 1826 Bolivian Constitution, and the Northern Army led by Abraham Lincoln to keep the Union, abolish slavery and advance the democratic ideal of government by, for and of the people. The state can be an instrument of justice against domination, even though it can also be and has frequently been an instrument of domination, as theorists from Plato, to Madison, Max Webber, Kenneth Arrow and Michel Foucault have emphasized. The idea is nicely captured by Marx's observation that the state is the executive committee of the dominant class. Looking at history and modern times around the world, one cannot deny the impressive frequency with which this statement rings true. In modern societies, the question suggested by democratic justice theory is not: collective action or not collective action; rather of what sort and does it put resources and power behind universal rights protecting basic interests or does it put them behind elite interests to dominate others.

This framework makes sense of some ideas in political theory. One is that only freedoms not involving domination are worth protecting. For instance, the freedom of "Every freeman of Carolina [to] have absolute power and authority over his negro slaves, of what opinion or religion soever" in the Fundamental Constitutions of Carolina to enslave black people is not a freedom democratic justice will protect- nor is the purpose of government "to protect the minority of the opulent against the majority", as Madison put it.

A second idea is that while power without justice is abusive, justice without power is empty. Democratic justice therefore aims to put power into justice and take justice into power. A third idea is that democratic justice is antithetical to personal, state and capital domination. All these sectors can be sources of domination and democratizing relations aims to shape social organizations that eliminate that domination.

A fourth idea is that the freedom worth our allegiance is not necessarily the freedom that comes from the lack of interference by the state. State interference to abolish slavery, to protect women's rights against rape, to defend domestic populations against imperial domination, to reign in financial sector abuses, to stop socially costly fraudulent propaganda for war, police brutality, poisonous products and political options defend and foment freedom; not diminish it. The purpose of the democratic state is to abolish domination and its main instrument is the distribution of power through a strategic mobilization of majority rule and use of resources, to break through illegitimate veto powers controlling the state for their benefit at the expense of justice. Given the relation between social order, power and rights, the state of democratic justice is the state of democratic citizenship (Shapiro, 2005, 2006, 2011, 2012; Sunstein \& Holmes, 2011; Restrepo, 2014). Democratic justice is given a loud voice in the first two articles of the International Covenant on Civil and Political Rights and the International Covenant on Economic, Social and Cultural Rights, which state that:

1) All peoples have the right of self-determination. By virtue of that right they freely determine their political status and freely pursue their economic, social and cultural development.

2) All peoples may, for their own ends, freely dispose of their natural wealth and resources...

Within the framework of democratic justice, the principle of affected interests is a central pillar of the legitimacy of a social order, including that which is codified in law. It is thus that democratic justice makes sense of the appeal of Nelson Mandela's statement to the Apartheid South African court that he should not be bound by "a law which neither I nor any of my people had any say in preparing" (Mandela, 1979, p. 664; cited in Shapiro, 2003). Decisions, particularly collective structural decisions, should take into account the interests of those affected by those decisions, presumptively having those whose interests are affected participate in the formation of those decisions. As Shapiro states: "if you are affected by the results, you are presumptively entitled to a say" 
(Shapiro, 2003, p. 220). This principle acts as a useful if imperfect wedge against domination. It of course seems unappealing that slave owners should have a say to keep their slaves, even if emancipation affects their interests. However, the problem is usually not whether the powerful have a say, as they by their power de facto do; rather it is whether others need to be included into the decision-making process. In the ideal, democracy as a social, including political and economic, system of free people (uncoerced and unmanipulated, epistemically, violently nor economically) communicating and making decisions; which leads to self-correction against domination, which in turn frees people making decisions, which in turn enables them to better secure their rights and conduct themselves toward the common good. Thus, unlike minimalist neoliberal democracy, democratic justice in this scheme aims at the ideal of universal human rights, not just privileges for elites; campaign promises of elected government are binding, not just political communication vehicles for attaining and maintaining power in the name of freedom of expression; and political battles between different policy alternatives embodied in their proponents are justified because they help educate and choose better paths toward the common good, which is decided by majority voting in open communication of ideas where fraud is not for sale. The principle of affected interest pays attention to who is affected by decisions, without discrimination based on whether they are Ecuadorian, Colombian, from the United States, or elsewhere; whether you are rich or poor; have dark or light skin; man or woman; are young or old; have a disability or don't; born or yet to be born; or whether you are in a powerful class or not. The important thing is having an affected interest.

The Buen Vivir version of democratic justice brings decolonization, including epistemic decolonization, into the theoretical mix. Interestingly, Locke and Madison are two central references of democratic justice for Ian Shapiro. However, it seems a truism that central private and public participants of slavery are unlikely champions for inspiring any form of political theory of freedom, democracy or justice. As is well known, Locke was one of the authors of the cited Fundamental Constitution of the Carolinas which enshrines racist slavery as a fundamental right of members of his race and class, he never challenged constitutional slavery, while being a shareholder in the Royal Africa Company (Losurdo, 2006; Quiggin, 2015). Madison, himself a slave-owner, of course, spearheaded the founding of a constitutionally established federal slave state, including Article 4's "slave clause" which read thus: "No person held to service or labour in one state, under the laws thereof, escaping into another, shall, in consequence of any law or regulation therein, be discharged from such service or labour, but shall be delivered up on claim of the party to whom such service or labour may be due". It is an odd choice for the one who justifies the existence of government based on the fact that people are not angels, recognizing that those with the will and power to dominate others will do it, and that government would itself not be constituted by angels (Madison, 1788), that he should have advocated a frame that ensured and bolstered the right of those with the will and power to exert extreme domination over others and make it hard to change because of the complex system of checks and balances. Better champions of democratic freedom seem to be Bolivar, Lincoln and Mandela.

Seldom in democratic theory is it noticed that non-discriminatory application of the principle of affected interest includes taking into account the interests and recognizing the rights of non-human animals (some contributions which do take them into account are of course Singer, 1975; Zaffaroni, 2012; Donaldson \& Kymlicka, 2011; Restrepo \& Houtart, 2015). For different reasons, both people of future generations as well as non-human animals cannot participate in our decisions that affect them, but we nevertheless think those interests need to be taken into account. This is particularly important from the point of view of the decisions relating to our eating practices and other practices central to the sustainability and health of our ecological base: planet Earth. The emphasis on intergenerational and especially ecological justice, even recognizing constitutional rights to the Earth's ecosystem, is another prime radicalizing democratic justice feature of the Buen Vivir framework adopted by Ecuador.

\section{Citizens' Revolution}

Rafael Correa was elected into power bolstered by the dissatisfaction with the political, economic and social system of neoliberal elite democracy (1981-2006). This form of democracy had caused the dispossession of $20 \%$ of GDP of the bottom quintiles and accumulated it in members of the top quintile, average inequality increased as measured by the Gini Index and average economic growth was $0 \%$ (World Bank, 2017); poverty took root; banking interests had taken the state and caused the financial system to collapse in 1999, while undermining the consent of the governed as people rejected their political class in the highest proportion in the Americas (Latinobarómetro 1997-2005) and heads of state lasted just a year on average between 1996 and 2006; 15\% of the population had to emigrate (Jokisch, 2014); a Constitution (1998) was imposed on the population without their consent; Ecuador lost its national currency; murder rates tripled (UNODC, 2016); and a foreign military base was forcibly established on national territory. Not without interest, the Correa administration has constantly 
explicitly framed its actions in terms of freedom as non-domination, the importance of freedom with justice, the importance of unlocking veto-holding powers against democratic change to transition away from neoliberal orthodoxy and defending the supremacy of humanity over capital. In a Boston Globe editorial called "Real freedom requires justice" Correa put it thus:

The belief that the United States was in fact a formal democracy existed even while suffrage was the sole province of rich white men, and while African Americans were enslaved for a century and subjected to brutal racism and segregation for another century after their emancipation.

We find ourselves faced with a similar paradox in Latin America today. When the Latin American elites - including their corporate-owned media — speak of freedom and equality, they speak only for themselves. Like America's Founding Fathers who preached equality yet themselves were slave owners, Latin American elites have left out large swaths of the populations, leaving them poor, disaffected and disenfranchised. In many of our nascent democracies, "fundamental" rights are the province of the powerful.

Definitions of freedom and justice vary depending on where one sits, and for the 164 million in Latin America living in poverty - and the 68 million still in extreme poverty-there is neither justice nor freedom nor true democracy...

During our seven years of governing Ecuador, my party has led the movement to end this paradox by breaking the monopoly of the elites and democratizing our political process to truly be by, and for, the people. We have invested our resources smartly and for the majority of our people, especially the poorest. For instance, we have the largest ratio of public investment to GDP in Latin America (about 15 percent), while total public debt is just 23 percent of GDP, thanks to a tripling of tax revenue achieved through efficient and well-enforced tax collection-not tax increases. This massive public investment has resulted in historical transformations in education, health, childcare, roads, ports, airports, telecommunications, power generation, justice system, and security (Correa, 2014).

Fittingly, the political movement headed by Correa to replace the previous model was named the "Citizens' Revolution", under the mantle of a new Constitution, whose two main categories of campaign promises have been "payment of the social debt" and "changing the productive matrix" from one heavily benefit-concentrating and highly dependent on the primary sector to one of more equal distribution, more production, more intelligent production, and more ecological sustainability.

Next, we look at the ways in which the majority rule and national resources have been moved to break through veto powers to advance the universalization of citizenship rights in the context of structural challenges in the areas of internal politics and international relations. The main structural challenges of Ecuador, marked by entrenched agents with veto power, have been (1) an unstable state, co-opted by a political and economic class composed of parties too autonomous from, and rejected by, the general interests of the population ("partidocracia"), (2) entrenched dominant international actors alien to interests of wide domestic origin, (3) an unstable, unaccountable, liberalized financial sector which had captured state policy through its agents and media control, (4) a deeply concentrated, inefficient non-renewable and contaminating economy. Let us analyse the first two of these in turn, together with how the "Citizens' Revolution" responded and the results for democratic citizenship.

\section{Democratic Transformation against Political Domination}

In now publicly available cables from Wiki Leaks, the US embassy characterized Ecuador as "one of the most unstable, undemocratic and corrupt countries in Latin America (... with) political and economic systems, based on competition by entrenched elites" (Kenney, 2005).

To respond to the first mentioned problem of domination by an unstable autonomous rejected political class the "Citizens' Revolution" proposed the presidential candidature of Rafael Correa with no party representative in the Legislature, but with the capacity to mobilize; organized a referendum to create a Constituent Assembly to take its place and create a new Constitution with participation of the population in the process and in its approval; rapidly applied policies to expand political and social rights; and adopted state reform policies to support them.

An academic economist and political outsider, Correa was elected in the second round of the 2006 elections; again in 2009 after the 2008 Constitution was adopted; and then elected again in 2013. After two centuries of political instability, marked by quick popular disillusionment with existing political figures, exacerbated in the previous decade, Correa was elected by increasing margins of approval. In the first rounds he obtained $22.85 \%$ 
in 2006, 51.99\% in 2009 and $57.17 \%$ in 2013 (Consejo Nacional Electoral), thus displacing the block of traditional actors controlling the Executive. National and international polls showed widespread and increasing consent of the new government, reaching an all-time and global-scale high of $90 \%$ approval rating in the Mexico-based Mitofsky Survey in 2013. By way of comparison on the public trust measure, in 1997 Ecuador's president had the lowest public trust in the region (28\%), and still held last place by 2006 (sinking further to 9.8\%). Taking office in 2007, by 2008, the public trust had been multiplied by 5 and by 2013 Ecuador had the highest public trust in the president in the region (71.4\%) (Latinobarómetro, 2016). It should be noted that the statistically significant reasons for the Correa vote in 2013 are part of the network of aspects that need to be addressed to comply with the two broad campaign promises of social inclusion and changing the economy, as well as the general democratic justice scheme: good management of the economy, improvement of personal finances, combating poverty, has an interest in politics, promoting democratic principles, and the need of a "firm hand" holding opposition parties in check (possibly read as veto powers) (Moncagatta, 2013).

With no party representation in the Legislative, the first day in office Correa pursued his key electoral promise of creating a Constituent Assembly to author a new Constitution, thus getting rid of two thick layers of false democracy represented in the 1998 Constitution and the existing Congress. The way this was pursued was through a Referendum, not to create an unpopular body to "reform" but instead draft and impose a Constitution as the National Assembly illegally did in 1998, but to create a Constituent Assembly elected by the people with "full powers" to draft the new Constitution. The "Yes" vote in the Referendum won with $82 \%$ popular adherence and in the elections for the composition of the Constituent Assembly the new party Alianza País, with $64 \%$ of the vote, was elected to 80 of the 130 seats, which displaced traditional parties from the Legislative (Consejo Nacional Electoral). Traditionally marginalized groups from the indigenous, women's and afroamerican movements regularly participated in the 10 thematic tables, 23 national forums with the participation of more than 11,500 citizens, and the Assembly processed more than 3,100 citizen proposals (Ramírez \& Ramírez, 2010, p. 94). Once again unlike the 1998 Constitution, the 2008 Montecristi Constitution was put to popular consideration and was adopted with more than $60 \%$ of the vote in favour.

This new force in the Legislative went on to obtain $45.86 \%$ in 2009 and $53.3 \%$ of the vote in 2013, while traditional parties (DP, PRE, ID, PRIAN and PSC) went from occupying practically all of the Legislative in 2006, to obtaining 43.83\% in 2009 and only 12.13\% in 2013 (National Electoral Council). In 2006, Ecuador had the lowest public trust in its Legislature in the region, with only $5.9 \%$, or less than half the next lowest in the ranking, Paraguay. By 2015, Ecuador's Legislative has the second highest public trust in the region, after Uruguay (Latinobarómetro, 2016).

In 2011 Correa called on a new referendum to reform the corrupt and co-opted Judicial System. Using ideas by Zaffaroni (2009) and Fiss (1993, 2003), Restrepo (2013) argued that the true independence of the judicial branch is not when it does whatever its members decide to do. Sometimes their members are incompetent, corrupt and have been agents of the worst kind of oppressors. An eloquent example of this was pointed out by Fiss when he noted that the president of the Supreme Court of Chile Enrique Urrutia Manzano greeted the 1973 military coup by placing the presidential band around Pinochet and stating that the Judicial Branch is in his hands. There is no justice-based imperative to not interfere with such a court in order to set one up that performs its duty. The judicial independence worth having is when justices perform their responsibility to administer justice applying the laws in accordance with their competent understanding of people's rights, without undue political, security or economic interference. To this end, amongst other measures, the United Nations Basic Principles on the Independence of the Judiciary were put into practice: the creation of a Judicial Council to govern and administrate the branch, the installation of open public merit-based competitions as the system for being selected as a judge and the creation of a Judicial School to train members of the judiciary in their specialized task. Judicial productivity, measured by the coefficient of cases initiated and case resolutions has increased by $264 \%$ from 2009 to 2015 (SNI, 2016). Latinobarómetro data confirm that public trust in the Judicial System has increased by $345 \%$ in proportional terms, from 2007 to 2015 , increasing its comparative position from last in the region to within the top three in the region, after Costa Rica and Uruguay. Recently, the president of the Interamerican Court of Human Rights, Roberto Caldas, has catalogued the changes in the Justice System in Ecuador as "perhaps the most important in the world" (Andes, 2016). Failure to comprehend that democratization must include democratic intervention wherever there are illegitimate dominating powers made the political party of Ruptura 25 deflect from the Citizens' Revolution coalition, even though its leaders never disputed the corruption and lack of judicial service that existed.

Institutionally jump-starting this kind of democratic judicial independence has implied that disputes have their day in a sound court. Two classic cases of this are the cases brought forth by victims of Chevron-Texaco's oil 
and waste spills, as well as victims of state crimes by military agents (Comisión de la Verdad, 2010). In the Chevron-Texaco case, they were processed in Ecuador, the place Chevron-Texaco argued in New York the case should be processed. They were found guilty and ordered to pay $\$ 9.5$ billion to their tens of thousands of victims Chevron refuses to pay and has launched a worldwide smear campaign involving "reporters", "academics" and websites to discredit the Ecuadorian state, particularly its Justice System, because "We can't let little countries screw around with big companies like this" (Zaitchik, 2014).

With respect to the right to life, we can see the murder rates stop increasing and rapidly decreasing, cutting rates by a factor of three.

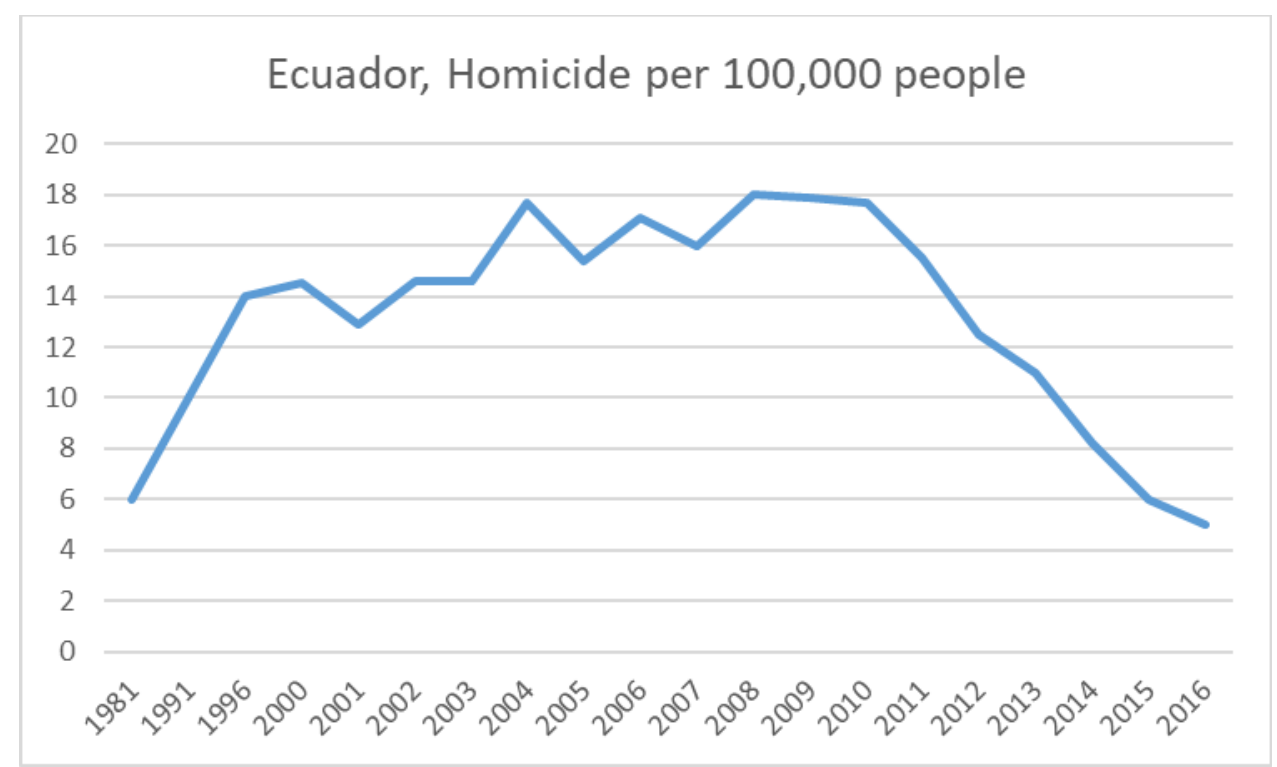

Figure 1. Homicide Rates in Ecuador. Fundar, United Nations Office on Drugs and Crime (2014) and In Sight Crime (2016)

As people found a new force to ally themselves with, traditional rejected parties were progressively voted out of the Legislative.

One of the key pillars of democracy is a free press. As we have theorised before, the vision of democratic justice is that the freedom worth defending is not the one that promotes domination. Noam Chomsky and Edward Norman (1988) have been pioneers in understanding the ways in which thought control by dominating elites can operate in democratic societies. The Propaganda Model, with its economic and political filters, helps one understand why media systems in the United States, for instance, promotes war and financial elites, at the expense of truth, knowledge and grave massive human rights violations, arguably constitutive of democracy itself. Even Madison said that democracy without public knowledge is but a "prologue to a farce or a tragedy, or perhaps both. Knowledge will forever govern ignorance, and a people who mean to be their own Governors, must arm themselves with the power which knowledge gives" (Madison, 1822). Yet, studies have shown that the market model of the media is the worst at public knowledge performance, compared to the mixed and public serviced models (Curran, Iyengar, Brink Lund, \& Salovaara-Moring, 2009; Aalberg, Aelst, \& Curran, 2010), consequently reducing democratic freedom of expression, based on knowing truths of public interest that promote genuine personal autonomy and private and public accountability (Restrepo, 2013).

Ecuador was no exception to the market model, where for instance banks owned much of television channels (Checa Godoy, 2012) and could use information to dominate the people. One instance of this was noted by the US ambassador Kristie Kenney (2004) in a Wiki Leaks-released cable, where she analysed the story of how majority stake-holders in two mayor banks and owners of mayor TV channels (Fidel Egas of Banco del Pichincha and Teleamazonas; and the Isaías brothers of Filanbanco and Gamavision and TC in Guayaquil, as well as CN3, a cable news station), made a pact to not report the news related to the 1999 banking crisis and their responsible agents. Kenney noted: particularly "troubling is the chilling effect of private and business interests on the media demonstrated by the TCTV-Teleamazonas dispute. It is an example of the economic 
interests which limit freedom of the press by inhibiting the press from performing its watchdog function... The fact that the press feels free to criticize the government, but not a fugitive banker and his family business interests, reveals much about where the power lies in Ecuador".

The Constitution (2008: Article 312 and 29th Transition Disposition) forced banking institutions and banking interests to disconnect from the mayor media by 2010, while the 2013 Communications Organic Law divided up the radioelectric frequencies between private $(33 \%)$, public $(33 \%)$ and community $(34 \%)$ control. Private media powers cried that this was an infringement on freedom of the press. Not without importance, Julian Assange, a prime agent of freedom of press in its democratic justice sense, was given asylum and has been protected within the Ecuadorian embassy since 2012, from where he has been promoting knowing fundamental truths of public interest, including serious state crimes the veracity of which has not been questioned by the perpetrators.

Thus it was that democracy transformed the state through the creation of a new Constitution, new composition of the Executive, the Legislative and Courts, created two new branches of government directly tied to holding government accountable (the National Electoral Council and the Council of Transparency and Social Control), and promoted opportunities for democratic freedom of expression.

Apparently unware of the irony, Osvaldo Hurtado, a prime leader of the former democracy-minimizing regimes, recently wrote a theoretically and empirically thin book called Twenty First Century Dictatorships: The Ecuadorian Case, denouncing how Ecuador has become a dictatorship.

\section{Democratic Sovereignty against Foreign Domination}

The main levers of domination by foreign institutions that hung over Ecuador as Correa came to power, were the Manta US military base, oil contracts that disproportionately benefited international corporations instead of Ecuador, an illegitimate debt burden and a foreign currency that undermines the capability of effective economic policy. These traditional veto-holding powers are directly opposed to the democratic justice model and these are the ways in which they have been faced.

Unmoved by complaints by the US embassy, Correa quickly removed the US military presence at the Manta base by not renewing the lease, saying that "If there's no problem having foreign soldiers on a country's soil, surely they'll let us have an Ecuadorean base in the United States" in reciprocity (Stewart, 2007). Since then various other US military personal have been asked to leave. It is not without interest (though in fairness a Cablegate Wiki Leaks search does not indicate foul play known at that classification level) that two days after she announced that the government would keep its campaign promise to not continue hosting a foreign military base, Guadalupe Larriva, the first civilian Defence Minister in 25 years and first woman to hold the post, died in air crash — at the Manta US military base (BBC, 2007).

With regard to assertion of sovereign ownership of natural resources against powers of foreign capital domination, the new Constitution makes this explicit and Ecuador adopted the 2010 Hydrocarbons Law, requiring that companies no longer operate under production sharing terms, but rather as service providers, which implied the renegotiation of the oil contracts with foreign companies. Between 1999 and 2001 Ecuador's fiscal income from commodities exploitation was $6.3 \%$ of GDP. With the Hydrocarbons Law this figure more than doubled to $13.5 \%$ of GDP (Bárcena, Prado, Fuentes, \& Pérez, 2013, p. 15). Oil income for the state rose from an average $32.1 \%$ of total state income between 2000 and 2009 to $39.6 \%$ between 2010 and 2014 (Arroyo \& Cossío, 2015, p. 35). State oil income rose from an average 7.2\% of GDP between 2000 and 2009 to $13.1 \%$ of GDP from 2010 to 2014, even though total proportional oil GDP rents declined (Arroyo \& Cossío, 2015, p. 36; Altomonte \& Sánchez, 2016, p. 181). According to the UN Economic Commission of Latin America, the law has allowed the state to approximately double its proportional participation in oil rents with respect to foreign oil companies, as between 2005 and 2008 the state received $35.2 \%$ of oil rents, while it received $69.3 \%$ between 2010 and 2013, which together with Mexico and Bolivia make it among the highest in the region (Altomonte \& Sánchez, 2016, pp. 190-191). This means that, based on these figures together with Oil Rents and Current dollar GDP figures from the World Bank, we can calculate that this law benefited the public with approximately $\$ 19,608,304,000$ which would otherwise have gone to multinational oil corporations between 2010 and 2013, though El Telégrafo (2017) reports that the net gain from 2011 to 2014 was $\$ 4,158$ million. Together with the oil boom of those years, this law allowed the state to take in substantial income destined for public investment in infrastructure, which together with Bolivia's is the highest in the region in proportional terms (Bárcena, 2015). This reverses the imperial scheme formulated by George Kennan $(1948,1950)$ of the US National Security Council that Latin America should be prevented from having popular governments that serve domestic needs with "our" natural resources and raw materials. 
Such infrastructure includes reconstructing Ecuador's public roads network from one of the worst in the region to one of the best and one of the highest education expenditures in world, tripling investment in this sector in absolute terms and doubling in proportional to GDP terms, which together with other policies has made Ecuador the country to most rise in this Competitiveness Index in the region (World Economic Forum, 2016; Ministry of Education, 2015). This has enabled the construction of 70 public Millenium Schools which have top quality standards used by low income families and 200 schools with International Baccalaureate recognition. Early childhood care has increased by more than tenfold in terms of the number of children who benefit, primary and middle school participation of the pertinent age groups have increased to $96 \%$, high school coverage has increased by a third its 2007 level, while improving teacher quality, providing free school meals and eliminating school fees (Ministry of Education, 2015). This has implied an ascent in the World Competitiveness Reports rankings from 2006 to 2015, from place 92 to 60 for Primary education, place 104 to 75 in Quality of education and place 98 to 63 in the quantity of education, which in turn has meant that Ecuador is the second country to most progress in Mathematics and the country to most progress in Reading in the region, according to Second and Third Regional Comparative and Explicative Studies by UNESCO.

Ecuador has also taken significant steps to construct sectors of the economy not in the traditional primary sector, with this state income. Apart from aggressive support for education at all levels to build the knowledge base for a different economy and society, while its proportional export contributions have not changed, its real GDP contribution from services and industrialized goods has grown $47 \%$ (not including military, bureaucracy, commerce nor financial services), while its primary sector only 22\% from 2007 to 2017 .

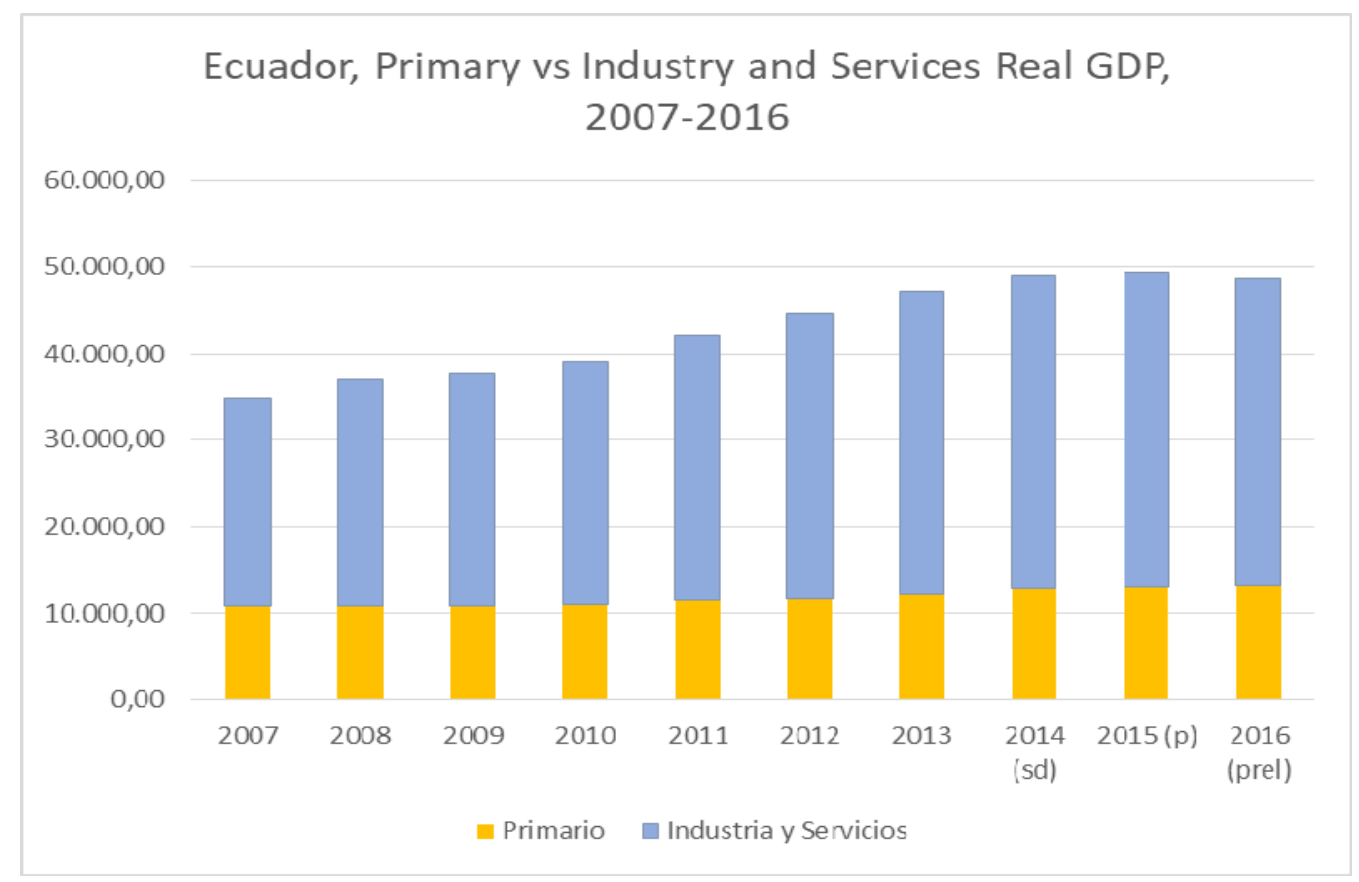

Figure 2. Primary vs Industry and Services Real GDP in Millions of USD, 2007-2016

Source: Ecuador Central Bank IEM 432.

Primary sector is defined as Aquaculture, Livestock, Hunting, Forestry, Fishing, Petroleum and Mines. Industry and Services is defined as Petroleum Refining, Manufacturing, Electricity and Water Supply, Construction, Accommodation, Food Services, Transport, Mail and Communications, Professional, Technical and Administrative Activities, Teaching, Social Services and Health. Commerce, Financial Services, Public Administration, Defence, Social Security Plans and Domestic Services are not included.

Further, Ecuador invested its resources in constructing eight mayor hydroelectric plants with the projected aim of transforming the overwhelmingly fossil origin of electricity consumption of the country to $92 \%$ of electricity of renewable origin, one of the cleanest in the world, reducing 8.2 million tonnes of $\mathrm{CO} 2$ emissions and saving $\$ 1,000$ million a year in energy imports (Constante, S., 2016; Constante, J., 2016). By 2016 Ecuador has 
increased supply by $76 \%$ of its 2006 level to $82 \%$ of its electricity needs from this renewable source (MEER, 2016; EC 486, 2016).

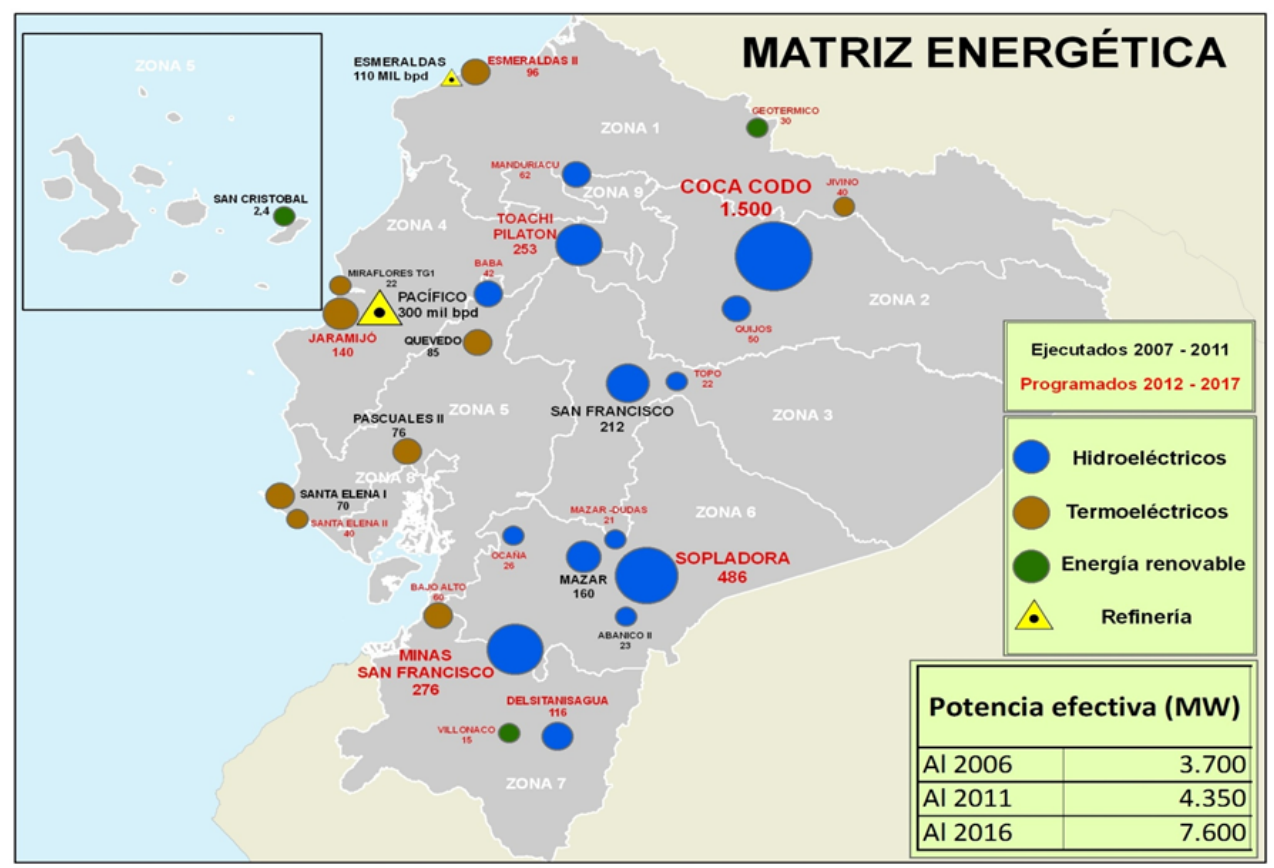

Figure 3. Senplades

It is a frequent statement that Ecuador's recent rise is due to pure luck because of an oil boom. However, this would not have been possible without the new legal framework and renegotiation of the oil contracts and an effective will to carry out these social rights infrastructure projects. Further, a recent global study by the Boston Consulting Group, looking at countries performance in converting wealth into well-being in oil producing nations (measured by an indicator composed of Income per capita, Economic stability, Employment, Income Inequality, Civil Society, Governance, Education, Health, Environment and Infrastructure) places Ecuador outside the norm and at the top of world nations translating oil wealth into social welfare.

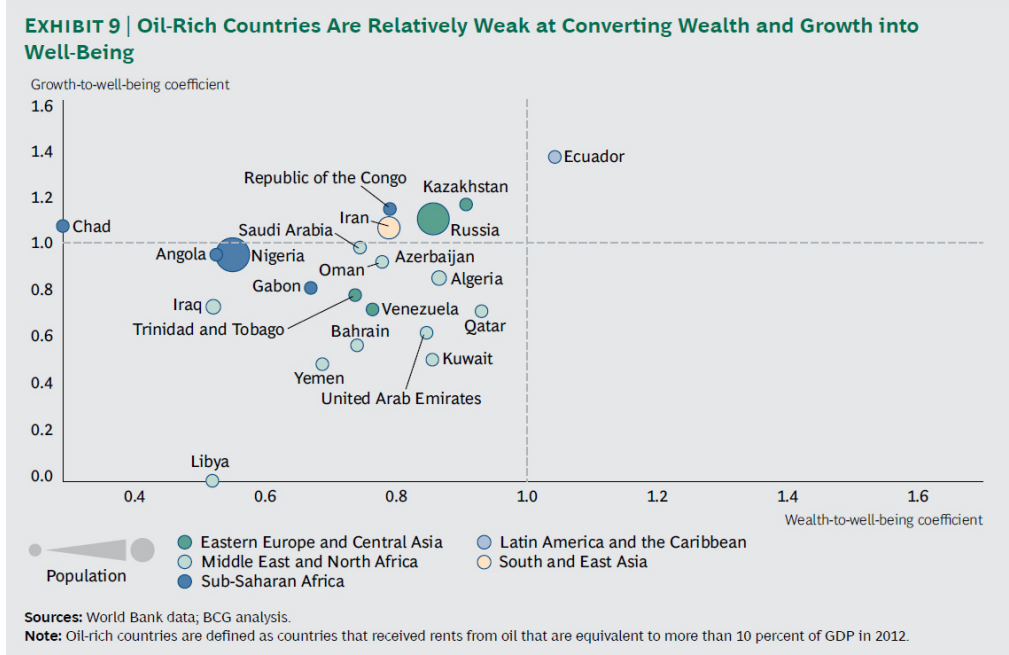

Figure 4. Beal, Douglas, Enrique Rueda-Sabeter \& Shu Heng (2015) 
The report states that "as a group, oil-rich nations are below average at converting both wealth and growth into well-being. The exception is Ecuador, which has a growth-to-well-being coefficient well above the median and has made strong progress in income equality and infrastructure" (Beal, Rueda-Sabeter, \& Heng, 2015, p. 26). Ecuador is also an exception in terms of using its oil revenue to transform its energy matrix into a much cleaner renewable one.

Ecuador had acquired a high public debt with little legitimacy and whose beneficiaries were local and international elites. Part of the debt was acquired under the military dictatorship of the 1970s and paying an interest rates that rose from $6 \%$ to $20 \%$. The Hurtado and Febres Cordero governments had transferred private debts to the public in an inverse Robin Hood move, which multiplied the public debt by a factor of 3.5, in the so called sucretization process between 1983 and 1988, where luxury clubs such as Quito Tenis Golf Club, the Pacific Bank Club, Horseshoe Riding Club, the Ballenita Club and others, where bailed out (Acosta, 2008). Public foreign debt reached its peak at 94\% of GDP driven by efforts to bail out the banks collapsing in 2000 . They had been deregulated but assured state assistance under the Agency to Insure Deposits Law and the 1998 Constitution. The Correa administration moved to make an official audit of the public debt, whose conclusions included that a portion of it was contracted illegally and illegitimately. Consequently, Ecuador refused to pay for those portions of its debt. These brought the value of the bonds down and Ecuador paid them off at this lower price, to avert the more costly route of defending the country against massive lawsuits. This strategic defence of the people against international financier domination saved the country approximately $\$ 7,000$ million (about 7\% of today's GDP), including interests. This is what the evolution of Ecuador's public foreign debt looks like.

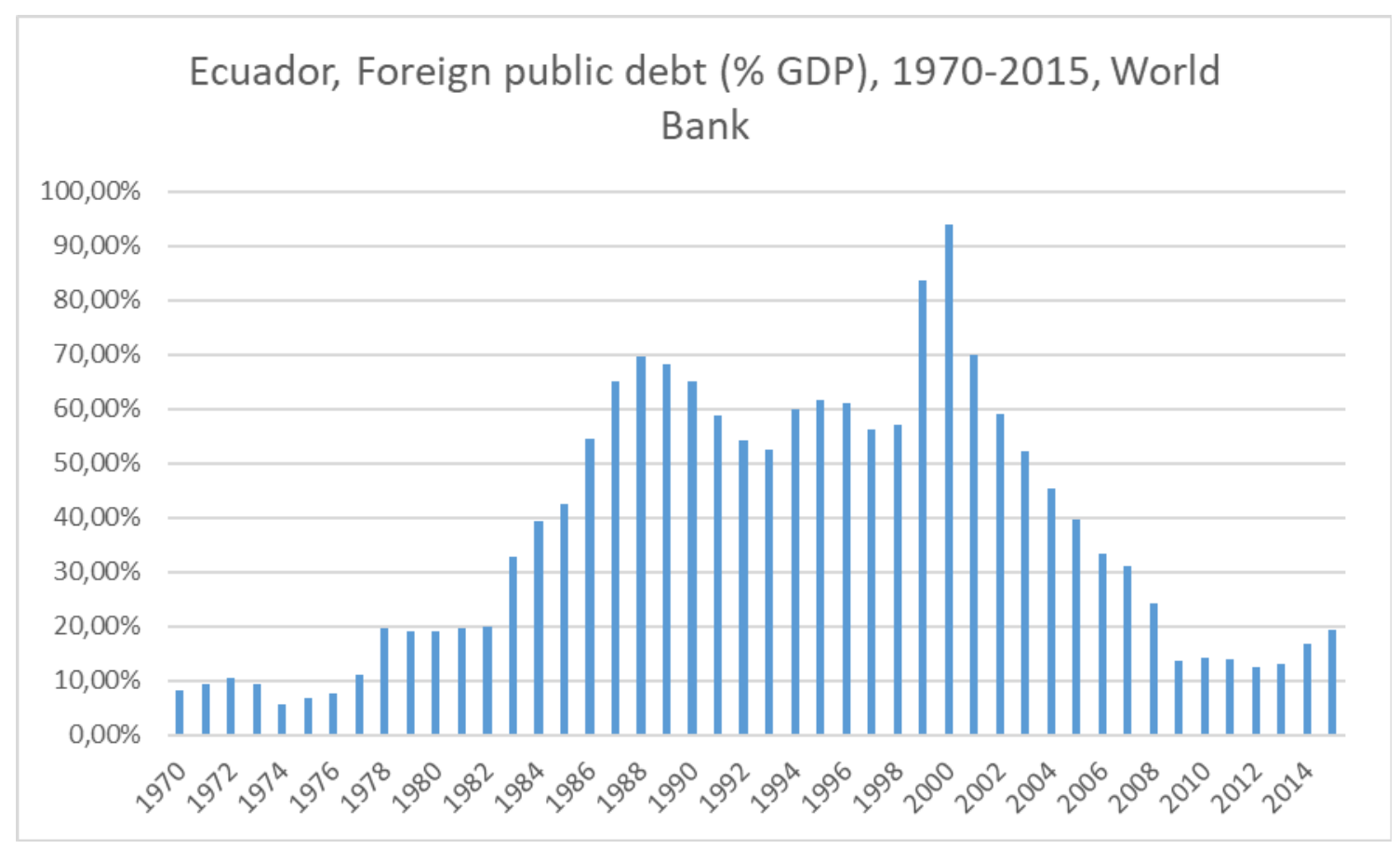

Figure 5. World Bank data (2016)

With this move, Ecuador cut off the main neoliberal processes installed in the 1980's and 1990's. As Ecuador distanced itself from traditional international lenders, it came closer to China, whose growth and demand for natural resources and markets complemented Ecuador's need for new financing, its oil wealth and construction of infrastructure projects for which local capacity was insufficient. The above graph represents external public debt in accordance with international standards that make for international comparability.

Ecuador does not have currency sovereignty; it lost the Sucre in 2000, when President Jamil Mahuad froze people's bank deposits and changed the currency to the US dollar. This, of course, reduces monetary policy to controlling interest rates, directing capital accumulation and managing debt to counteract factors reducing the money supply and distribution. The money supply has been affected by the collapse of exports in 2008 (its two main external sources of income, oil and remittances), as a result of the world economic crisis, and 2014-present, 
as oil prices collapsed again and an estimated $50 \%$ increase in the cost of the dollar with respect to practically all pertinent competitors and markets (United States, Europe, Colombia and Perú), a hit by El Niño, possible Cotopaxi volcano eruption and a deadly earthquake with a magnitude of 7.8 on the Richter scale in April 2016, that along with 671 deaths, destroyed 3\% of GDP.

In 2008 , oil prices collapsed $79 \%$, while constituting $62 \%$ of export earnings and $34 \%$ of government revenue. These external shocks are proportionately equivalent to the collapse of the housing bubble in the United States. To protect the rights and welfare of the people against these external shocks, the government implemented a 5\% of GDP stimulus by accelerating increases in expenditure in areas of housing, education and health, instead of giving it to the financial elites (Barofsky, 2012) which cut short the recession to one semester, after which the economy continued to grow (Weisbrot, Lefebvre, \& Johnston, 2013). Since 2014, Ecuador continues to struggle with its harsh external conditions with credit, protections on workers, national industry and continued high social rights expenditures.

\section{Conclusion}

Between 1981 and 2007, Ecuador experienced neoliberal reforms coupled with an elite form of democracy. These led to slow growth, upwards redistribution, and political and economic instability. Since then, Ecuador engaged in a Citizens' Revolution to counteract these economic and political forms of domination. In this paper, a few elements of the theoretical understanding of democratic justice inspired by Buen Vivir are advanced, and their policy-wise national applications in reconfiguring the political institutions that shape the state and its international relations. The Citizens' Revolution has advanced the democratization of the Constitution, the Executive, the Legislative, the Judicial system, political rights, the right to life, freedom of expression, national natural resources and investments, territorial sovereignty, external debt, as well as social rights and the welfare state. It remains to be seen whether such progress can be sustained in future administrations as "austerity" policies are advocated, the Moreno government distances himself from the base that brought him to power and high level corruption cases are processed. How the Citizens' Revolution ranks in breaking capital and ecological domination in a democratization process is a pending topic, for a sequent analysis.

\section{References}

Aalberg, T., Aelst, P., \& Curran, J. (2010). Media systems and the political information environment: A cross-national comparison. The International Journal of Press/Politics, 15, 255-271. https://doi.org/10.1177/1940161210367422

Acosta, A. (2008). Sucretización: Un atraco al alimón? Quito: FLACSO.

Altomonte, H., \& Sánchez, R. (2016). Hacia una nueva gobernanza de los recursos naturales en América Latina y el Caribe. Santiago: Comisión Económica para América Latina. https://doi.org/10.18356/0edf6614-es

Andes. (2016). Ecuador, uno de los países que más cambió la justicia en los últimos tiempos. Andes. Retrieved from

http://www.andes.info.ec/es/noticias/ecuador-uno-paises-mundo-mas-cambio-justicia-ultimos-tiempos-presi dente-corte-idh.html

Arroyo, A., \& Cossío, F. (2015). Impacto fiscal de la volatilidad del precio del petróleo en América Latina. Santiago: Naciones Unidas.

Banco Central del Ecuador. (2016). Cifras del Sector Petrolero. Quito: BCE. Retrieved from https://contenido.bce.fin.ec/documentos/Estadisticas/Hidrocarburos/SerieCifrasPetroleras.xlsx

Banco Central del Ecuador. (2017). Informe Estadístico Mensual IEM 1985. Quito: Banco Central.

Bárcena, A. (2015). Inauguración de la VIII Conferencia Estadística de las Américas. Quito: CEPAL.

Bárcena, A., Prado, A., Fuentes, J. A., \& Pérez, R. (2013). Fiscal panorama of Latin America and the Caribbean: Tax reform and renewal of the fiscal covenant. Santiago: CEPAL.

Barofsky, N. (2012). Bailout: An inside account of how Washington abandoned Main Street while rescuing Wall Street. New York: Free Press.

BBC. (2007). Crash kills Ecuador's defense chief. BBC. Retrieved from http://news.bbc.co.uk/2/hi/americas/6297093.stm

Beal, D., Rueda-Sabeter, E., \& Heng, S. (2015). Why well-being should drive growth strategies. Boston: Boston Consulting Group. 
Becerra, R. (2016). Alcance del artículo "Cuantificación de los subsidios de derivados del petróleo a los hidrocarburos en el Ecuador". In Petróleo al Día, Boletín Estadístico del Sector de Hidrocarburos. Quito: Observatorio de Energía y Minas.

Burgos, G. (2003). “¿Qué se entiende hoy por independencia judicial? Algunos elementos conceptuales”. In B. Germán (Ed.), Independencia judicial en América Latina: ¿De quién? ¿Para qué? ¿Cómo? (pp. 7-40). Bogotá, Instituto Latinoamericano de Servicios Legales Alternativos.

Checa Godoy, A. (2012). La banca y la propiedad de medios: El caso de Ecuador. Revista Latina de Comunicación Social, 67, 125-147. https://doi.org/10.4185/RLCS-067-950-125-147

Chomsky, N., \& Herman, E. (1988). Manufacturing consent. New York: Pantheon Books.

Comisión de la Verdad. (2010). Sin verdad no hay justicia. Comisión de la Verdad: Quito.

Comisión para la Auditoría Integral del Crédito Público. (2008). Informe Final de la Auditoría Integral de la Deuda Ecuatoriana. Quito: Auditoría Integral del Crédito Público.

Constante, J. (2015). ¿Cómo se genera la energía eléctrica en Ecuador? In El Telégrafo. Retrieved from http://www.eltelegrafo.com.ec/noticias/punto-de-vista/1/como-se-genera-la-energia-electrica-en-ecuador

Constante, S. (2016). Ecuador refuerza su apuesta por la energía hidroeléctrica. In El Pais. Retrieved from $\mathrm{http} / / /$ internacional.elpais.com/internacional/2016/04/14/america/1460586851_057240.html

Correa, R. (2014). Real freedom requires justice. In Boston Globe. Retrieved from https://www.bostonglobe.com/opinion/2014/04/09/real-freedom-requires-justice/m5aUIBXL3JsQobAQCAt $\mathrm{rsO} /$ story.html

Curran, J., Iyengar, S., Brink Lund, A., \& Salovaara-Moring, I. (2009). Media System, Public Knowledge and Democracy. European Journal of Communication, 24, 5-26. https://doi.org/10.1177/0267323108098943

Donaldson, S., \& Kymlicka, W. (2011). Zoopolis: A political theory of animal rights. Oxford: Oxford University Press.

EC 486. (2016). Coca Codo Sinclair opera con 6 turbinas que generan 1113 Megavatios para el país. Enlace Ciudadano.

Retrieved

from http://www.elciudadano.gob.ec/coca-codo-sinclair-opera-con-seis-turbinas-que-generan-1-113-megavatiospara-el-pais-video/

El Telégrafo. (2014). Alberto Padilla, expresentador de CNN, denuncia campaña de los hermanos Isaías contra $\begin{array}{llllll}\text { Ecuador. In } & \text { In } & \text { Telégrafo. } & \text { Retrieved }\end{array}$ http://www.eltelegrafo.com.ec/noticias/informacion-general/1/alberto-padilla-expresentador-de-cnn-denunc ia-campana-de-los-hermanos-isaias-contra-ecuador

El Telégrafo. (2017). La década de Correa. In El Telégrafo.

Fiss, O. (1993). The right degree of independence. In I. Stotsky (Ed.), Transition to Democracy in Latin America: The role of the judiciary. Oxford: Westview Press.

Fundar. (2005). El ranking de la violencia en América Latina. Buenos Aires: Fundación Fundar.

InSight Crime. (2016). In Sight Crime's 2015 Latin America Homicide Round-up. Retrieved from http://www.insightcrime.org/news-analysis/insight-crime-homicide-round-up-2015-latin-america-caribbean

Jay, W. (1833). Life and Opinions of John Jay (Vol. 1). New York: Harper.

Jokisch, B. (2014). Ecuador: From Mass Emigration to Return Migration? Migration Information Source, The Online Journal of the Migration Policy Institute. Washington D.C. Retrieved from http://www.migrationpolicy.org/article/ecuador-mass-emigration-return-migration

Kennan, G. (1948). Review of Current Trends, U.S. Foreign Policy. Policy Planning Staff, 23, 509-529.

Kennan, G. (1950). 2nd Regional conference of US chiefs of mission in Rio de Janeiro. In Office files of the assistant secretary of state for Latin American affairs Edward G. Miller 1949-1953.

Kenney, K. (2004). How free is the press in Ecuador? Public Library of US Diplomacy. Retrieved from https://www.wikileaks.org/plusd/cables/04QUITO2740_a.html

Kenney, K. (2005). Transforming Ecuador: Action plan for democracy and stability. Public Library of US Diplomacy. Retrieved from https://wikileaks.org/plusd/cables/05QUITO2416_a.html 
Latinobarómetro. (1997). Informe Latinobarómetro. Santiago. Retrieved April 1, 2014 from $\mathrm{http}: / / \mathrm{www}$. latinobarometro.org/latContents.jsp

Latinobarómetro. (2002). Informe Latinobarómetro. Santiago. Retrieved April 1, 2014 from http://www.latinobarometro.org/latContents.jsp

Latinobarómetro. (2005). Informe Latinobarómetro. Santiago. Retrieved April 1, 2014 from http://www.latinobarometro.org/latContents.jsp

Latinobarómetro. (2011). Informe Latinobarómetro. Santiago. Retrieved April 1, 2014 from http://www.latinobarometro.org/latContents.jsp

Latinobarómetro. (2015). Confianza en el poder judicial, Santiago. In Latinobarómetro. Retrieved from http://www.latinobarometro.org/latOnline.jsp

Losurdo, D. (2006). Liberalism: A counterhistory. London, Verso.

Madison, J. (1788). Federalist 10. The Federalist Papers. Independent Journal.

Madison, J. (1822). Letter to W. T. Barry. Madison in Robert Yates Notes of the Secret Debates of the Federal Convention of 1787, Taken by the Late Hon Robert Yates, Chief Justice of the State of New York, and One of the Delegates from That State to the Said Convention.

Mandela, N. (1979). Address to the court before sentencing. In J. Ayo Langley (Ed.), Ideologies of Liberation in Black Africa, 1856-1970. London, Rex Collins.

Ministry of Education of Ecuador. (2015). Rendición de cuentas 2015. Quito: Ministry of Education.

Mitofsky Encuesta. (2010). Evaluación de mandatarios. México. Retrieved from http://consulta.mx/web/index.php/estudios-einvestigaciones/el-mundo

Mitofsky Survey. (2013). Evaluación de mandatarios. México. Retrieved from http://consulta.mx/web/index.php/estudios-e-investigaciones/el-mundo

Moncagatta, P. (2013). El porqué del voto por Rafael Correa. Retrieved April 1, 2014, from http://www.gkillcity.com/articulos/el-miradorpol\%C3\%ADtico/el-porqu\%C3\%A9-del-voto-porrafael-corre a

Naciones Unidas. (n.d.). Firmas y ratificaciones del Pacto Internacional de Derechos Civiles y Políticos. Retrieved from $\mathrm{http} / /$ treaties.un.org/Pages/ViewDetails.aspx?src=TREATY\&mtdsg_no=IV-4\&chapter=4\&lang=en

Naciones Unidas. (n.d.). Principios básicos relativos a la independencia de la judicatura. Retrieved from http://www2.ohchr.org/spanish/law/judicatura.htm

Quiggin, J. (2015). Locke against freedom. In Jacobin. Retrieved from https://www.jacobinmag.com/2015/06/locke-treatise-slavery-private-property/

Ramírez, F., \& Ramírez, J. P. (2005). La estampida migratoria ecuatoriana: Crisis, redes transnacionales y repertorios de acción migratoria. Quito: Centro de Investigaciones Ciudad.

Restrepo, R. (2013). Democratic freedom of expression. Open Journal of Philosophy, 3, 380-390. https://doi.org/10.4236/ojpp.2013.33058

Restrepo, R. (2014). Independencia judicial y democracia en Ecuador. In R. Restrepo (Ed.), Pugna de poderes, crisis orgánica e independencia judicial. Quito: IAEN.

Restrepo, R. (2017). Neoliberalism and elite democracy in Ecuador (1981-2007). Review of European Studies, 9 , 126-139. https://doi.org/10.5539/res.v9n3p126

Restrepo, R., \& Houtart, F. (2015). Buen vivir y la necesidad de cambios alimentarios: El caso de la carne. Ambiente y Sociedad, 655.

Shapiro, I. (2005). El Estado de la teoría democrática. Barcelona: Bellaterra.

Shapiro, I. (2006). Moral foundations of politics. New Haven: Yale University Press.

Shapiro, I. (2011). La teoría de la democracia en el mundo real. Buenos Aires: Marcial Pons.

Shapiro, I. (2012). On Non-Domination. University of Toronto Law Journal, 62, 293-335. https://doi.org/10.3138/utlj.62.3.293

Singer, P. (1975). Animal liberation: A New Ethics for our Treatment of Animals. New York, Random House. 
Sistema Nacional de Información. (2016). Objetivos e indicadores del Plan Nacional del Buen Vivir: Transformar la Justicia. In Indicador: Tasa de Resolución. Secretaría Nacional de Planificación para el Desarrollo. Retrieved from http://indestadistica.sni.gob.ec/QvAJAXZfc/opendoc.htm?document=SNI.qvw\&host=QVS@kukuri\&anony mous=truehttp://indestadistica.sni.gob.ec/QvAJAXZfc/opendoc.htm?document=SNI.qvw\&host=QVS@kuk uri\&anonymous $=$ true\&bookmark=Document/BM71

Stewart, P. (2007). Ecuador wants military base in Miami. In Reuters. Retrieved from http://uk.reuters.com/article/ecuador-base-idUKADD25267520071022

Sunstein, C., \& Holmes, S. (2011). El costo de los derechos: Por qué la libertad depende de los impuestos. Buenos Aires: Siglo 21 Editores.

UNESCO. (2006). Second regional comparative and explicative study. Paris: UNESCO.

UNESCO. (2013). Third regional comparative and explicative study. Paris: UNESCO.

United Nations. (1969). Vienna Convention on the Law of Treaties. United Nations.

UNODC. (2014). Intentional Homicide, Count and Rate per 100,000 Population. In Global Study on Homicide. New York: United Nations Office on Drugs and Crime.

World Bank. (2016). Data. Retrieved from http://data.worldbank.org/

World Economic Forum. (2016). World Competitiveness Report. Geneva: World Economic Forum.

World Health Organization. (n.d.). Statistics on Homicides, Suicides, Accidents, Injuries, \& Attitudes towards Violence. Retrieved from http://www1.paho.org/English/AD/DPC/NC/violence-graphs.htm\#homicides-n-sa

Zaffaroni, R. (2009). Dimensión política de un poder judicial democrático. In S. Andrade, \& L. F. Ávila (Eds.), La transformación de la Justicia. Quito: Ministry of Justice and Human Rights.

Zaitchik, A. (2014). Sludge match: Inside Chevron's 9 billion legal battle with Ecuadorian villagers. In Rolling Stone.

Retrieved from http://www.rollingstone.com/politics/news/sludge-match-chevron-legal-battle-ecuador-steven-donziger-201 40828

\section{Copyrights}

Copyright for this article is retained by the author(s), with first publication rights granted to the journal.

This is an open-access article distributed under the terms and conditions of the Creative Commons Attribution license (http://creativecommons.org/licenses/by/4.0/). 